\title{
Erzurum İlinde İçme Suyu İçin Ödeme İstekliliği Üzerine Etkili Olan Faktörlerin Belirlenmesi
}

\author{
Doç. Dr. Ahmet Semih Uzundumlu ${ }^{{ }^{*}}$ \\ Doç. Dr. Özden Fakıoğlu² \\ Dr. Öğr. Üyesi Mine Köktürk ${ }^{3}$
}

Geliş tarihi: 26.09 .2019

Kabul tarihi: 22.10 .2019

\section{Atıf bilgisi:}

IBAD Sosyal Bilimler Dergisi

Sayı: 5 Sayfa:

Yıl: 2019 Dönem: Güz

This article was checked by Turnitin. Similarity Index $18 \%$.

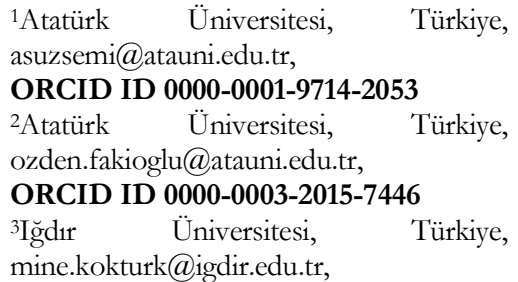

* Sorumlu yazar

\section{ÖZ}

Belediyelerin topluma daha hijyenik, daha güvenilir içme sularını ulaştırmaları yıllar geçtikçe daha fazla önem arz etmektedir. Ancak bu amacı gerçekleştirmek belediyelerin çok büyük yatırımlar yapmasını gerektirmektedir. Bu yatırımları yerine getirmesinde toplumun katkısı da önemli bir yere sahiptir. Bu çalışmadaki amaç içme suyunda toplumun belediye hizmetlerinin iyileştirmesine yönelik katkıda bulunup bulunmayacağını araștırmaktır. Çalıșmada hanelerin \%65.7'sinin belediye suyunun 1 litresine 50-80 kuruş ödemeye istekli olduğu tespit edilmiştir. Ayrıca hanelerde meyve suyu tüketimi arttıkça içme suyu için ödeme istekliliği artmaktadır. Bunun dışında hanelerdeki birey sayısı arttıkça, hane reisinin eğitim yılı azaldıkça, hane reisinin mesleği esnaflık olunca, çeşme suyunun maliyeti arttıkça ve tüketicilere sunulan ödeme istekliliği fiyatı arttıkça tüketicilerin içme suyu için ödeme istekliliği azalmaktadır. Tüketiciler güvenilir içme sularına ödedikleri su faturasına yaklaşık 3.2 katı kadar ödemeye razıdırlar. $\mathrm{Bu}$ nedenle belediyeler tüketicilere daha hijyenik ve tadı daha güzel suları ulaştırmak için altyapı hizmetlerini iyileştirmesinde toplumun desteğini alabilir.

Anahtar Kelimeler: Ödeme istekliliği, İçme suyu, İçilebilir su, Hijyen, Erzurum. 


\title{
Determining of the Effective Factors on Willingness to Pay for Drinking Water in
} Erzurum Province

\author{
Assoc. Prof. Dr. Ahmet Semih Uzundumlu ${ }^{*}$ \\ Assoc. Prof. Dr. Özden Fakığ̆lu \\ Asst. Prof. Dr. Mine Köktürk ${ }^{3}$
}

First received: 26.09 .2019

Accepted: 22.10 .2019

Citation:

IBAD Journal of Social Sciences

Issue: $5 \quad$ Pages: 153-163

Year: 2019 Session: Fall

This article was checked by Turnitin Similarity Index $18 \%$.

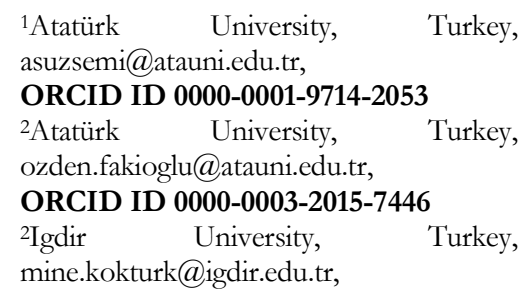

* Corresponding Author

\begin{abstract}
Over the years, it has been more important for municipalities to supply more hygienic and reliable drinking water to the public. However, municipalities need to make huge investments for achieving this objective. The contribution of society in carrying out these investments has an important place. The aim of this study to investigate whether the community can contribute to the improvement of municipal services in drinking water. In the study, it has been found that $65.7 \%$ of households are willing to pay 50-80 cents per 1 liter of municipal water. In addition, like fruit juice consumption increases, willingness to pay for drinking water increases. Also, increase of household size, decrease of the education level of household head, increase of fountain water cost and increase of water price that consumers are willing to pay cause consumer to decrease willingness to pay for drinking water. Besides, having a profession as artisan decrease consumers' willingness to pay for drinking water, too. Consumers are willing to pay about 3.2 times more for water bill to have reliable drinking water. Therefore, municipalities can get the support of society in improving infrastructure services for providing consumers with more hygienic and tastier waters.
\end{abstract}

Keywords: Willingness to Pay, Drinking water, potable water, Hygiene, Erzurum. 


\section{GİRIŞ}

Su, insanların hayatlarını devam ettirmelerinde ve sağlıklı bir yaşam sürdürebilmelerinde çok önemli bir yere sahiptir. Ancak günümüzde dünya nüfusundaki hızlı artışın yanı sıra teknolojideki ilerlemelerin çevre kontrolü olmadan kullanımı su kaynaklarını kirletmekte ve iklimde olumsuz sonuçlar ortaya çıkarmaktadır. Bu durum su kaynaklarını olumsuz etkilemekte bu da kaliteli içme suyuna ulaşmayı zorlaştırmaktadır (Lyytimäki ve Assmuth, 2015). Ayrıca dünya nüfusundaki artışa karşı1ık tatı su kaynaklarında bir artış olmadığı için insanların kullanabileceği tatlı su oranı giderek azalmaktadır (Alaş vd., 2009).

Dünyadan y1llık elde edilebilecek su rezervi $43750 \mathrm{~km}^{3} / \mathrm{y} 1 \mathrm{l}$ olup, bu su miktarının yüzeye dağılımı coğrafik ve iklimsel özelliklere göre değişmektedir (Karahan ve Angın 2008). Dünyanın su içeriğinin $\% 97.5$ 'i okyanuslarda tuzlu olarak ve \%2.5'i tatlı su olarak genelde Kuzey Kutbu ve Antarktika ile buzullarda bulunmaktadır. Bu tatlı su kaynaklarının \%68.7'si Kuzey Kutbu ve Antarktika'da, \%30.1'i buzullarda ve $\% 0.3$ 'ü yüzey ve yeraltı sularında bulunmaktadır. Yani dünyada bulunan toplam suyun yalnızca \%1'inin insanlar tarafından kolaylıkla kullanılabileceği anlamına gelmektedir. Ayrıca dünya nüfusunun dörtte biri nehirlerden ve göletlerden tatlı su almak için teknoloji sıkıntısı (Manju ve Sagar, 2017).

Dünyada 2.1 milyar insan hijyenik, güvenli ve kaliteli içme suyuna ulaşamamaktadır. Bireylerin güvenli, hijyenik ve kaliteli içme suyuna ulaşabilmesi için belediyeler tarafından iyi bir altyapı masrafı harcanmakta ve böylece daha sağlıklı toplumların yetişmesine imkan tanınmış olmaktadır. Böylece iyi altyapı sistemlerine ulaşamayan toplumlarda su kalitesi önemli bir sorundur (Guilfoos vd., 2019).

Dünya nüfusunun hızla artması ve sanayileşme, doğal kaynakların sürdürülebilirliğini zayıflatmakta ve insanların daha güvenilir içme sularına ulaşmasını zorlaştırmaktadır. Bu nedenle insanlar güvenilir sulara ulaşmak için fazladan ödeme isteğinde bulunabilmektedirler (Tanellari vd. 2015). Gelişmekte olan ülkelerde temiz suya daha fazla erişim için ayda 3-30 dolar arasında fazladan bir ödemeye istekli oldukları (Van Houtven vd., 2017); gelişmiş bir ülke olan Güney Kore'de de bireylerin \%3'ünün arıtılmamış musluk suyu içtiği ve modern su arıtma sistemi kurmak için fertlerin ayda minimum 2 \$ fazladan ödemede bulunabilecekleri tespit edilmiştir (Gschwandtner vd., 2018). Bireyler bu fazladan ödeme talebinde faturalarında \%2-7 arasında bir artışa olumlu bakmaktadırlar (Guilfoos vd., 2019).

\section{LITTERATÜR TARAMASI}

Son yıllarda özellikle gelişmekte olan ülkelerde belediye hizmetlerinin yapısal anlamda iyileştirilmesi ile tüketicilerin güvenilir içme suyuna fazladan ödeme isteğinde bulunup bulunmayacağı üzerine bazı araştırmalar yapılmıştır.

Brouwer vd. (2015), Kenya'da içme suyu filtresi için kentsel ve kırsal hane halkının ödeme istekliliğini araştırmışlardır. Çalışmada kentsel ve kırsal alanda 150+150 toplamda 300 anket yapmışlardır. Ödeme istekliliğini belirlemede Koşullu Değerleme (Contingent Valuation) yöntemini kullanmışlardır. Sonuç olarak kırsal ve kentsel alanda içme suyundan kaynaklanan hastalıkların çocuklarda görülme sıklığı arttıç̧a ve filtre fiyatı azaldıkça bireylerin ödeme istekliliğinin arttığını tespit etmişlerdir. Pazarlamacıların her iki kesim için de farklı pazarlama stratejileri geliştirmelerini önermişlerdir.

Del Saz-Salazar vd. (2015), Bolivya'da su sistemini geliştirmek için bireylerin ödeme istekliliğini araştırmışlardır. Çalışmada 324 biriyle görüşerek Koşullu Değerleme yöntemini uygulamak için iki aşamalı Heckman yöntemine başvurmuşlardır. Sonuç olarak bireylerin \%55'inin fazladan ödemeyi kabul ettiğini tespit etmişlerdir. Ödeme isteğini gelir, eğitim, ev sahibi olma ve su taşıma durumu pozitif, şişe su kullanımı ise negatif yönde etkilediğini tespit etmişlerdir.

Mezgebo ve Ewnetu (2015), Etiyopya'nın Nebelet şehrinde hane halkının iyileştirilmiş sulara ödemede bulunup bulunmayacağı tespiti amaçlanmıştır. Çalışma verileri 181 bireyle yüz yüze görüşülerek elde edilmiş ve ödeme istekliliğini etkileyen faktörlerin belirlenmesinde probit model kullanılmıştır. Hanelerin \%96'sının iyileştirilmiş su hizmeti sunumu için fazladan ödeme istediğinde bulunabileceklerini tespit etmişlerdir. Probit modeli sonuçlarına göre gelir, mesafe, su gideri, teklif 
fiyatı, eğitim, medeni durum ve cinsiyetin hane halkının su hizmetlerinin iyileştirilmesi için ödeme yapma isteği ile ilişkili olduğunu belirleyerek, yapılacak bir projede bu faktörlerin dikkate alınması gerektiğini önermişlerdir.

Rananga ve Gumbo (2015), Güney Afrika'nın Mutale Belediyesinin kırsal alanda su kalitesini artırmada bireylerin ödeme isteğinde bulunup bulunmayacağını 114 anket yaparak $\mathrm{X}^{2}$ analizi ile araştırmışlardır. Bireylerin \%90'ının belediye hizmetlerinden memnun olmadığı bu nedenle bireylerin \%95.5'inin 1 ton su için yaklaşı 25 GAR (10 TL) ödemeye razı olduklarını tespit etmişlerdir.

Tanellari et al.(2015), Kuzey Virginia ve Washington, D.C'nin Maryland banliyölerindeki tüketicilere mail yoluyla uygulanan anket çalışmalarına dayanan araştırmada, tüketicilerin içme suyu problemine yönelik iyileştirme programları için ödeme yapma istekliliğini ortaya koymaya çalışmışlardır. İçme suyu problemi olarak; suyun kalitesini, ev tesisat altyapısındaki küçük çaplı sızıntıları ve eskimiş kamusal altyapı sistemini değerlendirmişlerdir. Sonuç olarak herhangi bir iyileştirme programına ödeme yapma istekliliğinin önerilen iyileştirmenin maliyeti nedeniyle olumsuz etkilendiğini tespit etmişlerdir.

Twerefou vd. (2015), Gana'nın Accra-Tema Metropolitan bölgesinin en önemli sorunu olan içme suyunda kalite ve hijyen için Koşullu Değerleme yöntemini kullanarak ödeme istekliliğini araştırmışlardır. Çalışmada 315 kişi ile görüşüp, verileri sıralı probit yöntemini kullanarak analiz etmişlerdir. Hane halkının bir kova su için (17.5 lt), şu anda harcadıklarının yaklaşık 7 kat daha fazlası olan 0.10 Gana sedisini (11 krş) ödemeye razı olduğunu tespit etmişlerdir.

Del Saz-Salazar vd. (2016), kentsel su temini altyapısını iyileştirmek ve sızıntıları azaltmak için İspanya'daki Guadalquivir nehri havzasındaki tüketicilerin ödeme istekliliğini değerlendirmek amacıyla Koşullu Değerleme yöntemini kullanmışlardır. Çalışmada, bireylerin su faturalarında ortalama olarak $8.23 €$ ile $9.65 €$ arasında değişen bir ek ücret ödemeye razı olduklarını belirlemişlerdir.

Rodríguez-Tapia vd. (2017), Meksiko şehrindeki ailelerin kentteki kaliteli tedarik hizmetlerine güvenmek yerine, alternatif içme suyu kaynaklarını tercih ettiklerini ortaya koymuşlardır. Çalışmada daha iyi su kalitesi için hane halkının ödeme isteğini tahmin etmek için Sansürlü Tobit modelini kullanmışlardır. Daha iyi içilebilir su için fazladan ödeme istekliliğinde bulunan bireylerin ödeme isteği su faturasının \%3-4'ü kadar olduğunu ve ortalama aile gelirinin yaklaşık \%0.22'si kadar olduğunu belirlemiş̧lerdir. Sonuç olarak hanelerin kaliteli musluk suyu için ödeme yapma istekleri yıllık 34.5 milyon \$ iken, şişelenmiş su için yapılan harcama 380 milyon \$ olduğunu hesaplamışlardır.

Van Houtven vd. (2017), Çalışmada 60 araştırmadan elde edilen 171 ödeme istekliliği tahminini kullanarak, tahminlerdeki değişimi açıklayan potansiyel faktörleri incelemişlerdir. Hanelerin su erişimindeki iyileşmeler için ayda yaklaşık 3-30 \$ arasında bir ücret ödemeye istekli olduğunu belirlemişlerdir.

Gschwandtner vd. (2018), Güney Kore'deki Cheongju su tesislerinde gelişmiş su arıtma tesislerinin uygulanabilirliğini araştırmak için seçim deneyleri ve maliyet-fayda analizi yapmışlardır. Güney Kore'deki nüfusun yalnızca \%3'ünde arıtılmamış musluk suyu kullanıldığını ve gelişmiş su arıtma sistemi kurmak için ödeme istekliliğinin alt sınırının aylık ortalama $2 \$$ olduğunu tespit etmişlerdir

Guilfoos vd. (2019), Guatemala'nın dağlı bölgelerinde kullanım noktası, su kalitesi teknolojisi ve su kalitesi test hizmetleri için ödeme istekliliğini tahmin etmek amacıyla bu çalışmayı yapmışlardır. Çalışmayı hane halkının içme suyu kalitesini belirlemek için evlerden toplanan su örneklerinin ölçülmesi ve su kalitesi için ödeme isteğinin belirlenmesi çerçevesinde tasarlamışlardır. Sonuç olarak bireylerin 18 \$ tutarındaki su filtrelerinin ücretini ödemeye istekli olduklarını, su kalitesi ölçümlerinde "çok temiz" olarak tanımlanan hanelerde suda bakteri ölçümlerini belirlemişlerdir.

\section{AMAÇ VE KAPSAM}

Erzurum ilinde 2008 yılı itibariyle Palandöken Barajından içme ve kullanma suyu temin edilmeye başlanmıştır. Fakat barajdan gelen bu suyun içme suyu olarak kullanımı bir takım sorunlar meydana getirdiği için halkın büyük bir çoğunluğu içme suyunu ya damacana ya da daha fazla güvendikleri 
mahalle çeşmelerinden kullanmaya başlamışlardır. $\mathrm{Bu}$ nedenle Erzurum ilinde tüketicilerin demografik ve sosyal özelliklerine göre, güvenilir içme suyu için fazladan ödeme isteğinde bulunup bulunmayacağını tespit etmek amacıyla bu çalışma yapılmıştır.

\section{MATERYAL VE YÖNTEM}

\section{MATERYAL}

Araştırmanın ana materyalini, Erzurum ilini temsil edecek 400 hane halkıyla birebir yapılan anketler oluşturmuştur. Çalışma 2014 yılının Temmuz-Kasım aylarında sekiz anketörle yürütülmüştür. Katılımcılara, bireysel ve hanelerine ilişkin sosyo-ekonomik özellikleri ve su tüketim miktarı, su tüketim tercihi ve suda ödeme istekliliği hakkında sorular sorulmuştur. Ayrıca çalışmada ikincil veri olarak yerli ve yabancı bilimsel çalışma, dergi ve çeşitli yayınlar kullanılmıştır.

\section{YÖNTEM}

\section{Örnekleme Metodu}

Araştırmaya dahil edilen katılımcıların seçiminde "Oransal örnekleme yöntemi”; veri temininde ise "Yüz-yüze anket yöntemi" kullanılmıştır. Erzurum hane halkı ile ilgili bilgiler Erzurum Nüfus Müdürlüğü kayıtlarından elde edilmiştir. Örneklem hacminin belirlenmesinde aşağıdaki formülden yararlanılmıştır (Newbold, 1995; Sezgin ve Uzundumlu, 2019). Yöntemde \%95 güven aralığı, \%5 hata payı kullanılmıştır.

$$
n=\frac{N * p *(1-p)}{(N-1) * \sigma^{2}{ }_{p}+p *(1-p)}
$$

$\mathrm{n} \quad$ : Örnek büyüklüğ̈̈,

$\mathrm{N}$ : Tüketici sayıs1,

$\mathrm{r}$ : Ortalamadan sapma (\%5)

$\mathrm{Z}_{\alpha / 2}: \mathrm{z}$ cetvel değeri (1.96)

$$
\sigma_{\mathrm{p}}^{2} \text { : varyans } 1, \sigma_{p}^{2}=\left(\frac{r}{z_{\alpha / 2}}\right)^{2}=(0,0255)^{2}
$$

$\mathrm{p}$ : İşletme sayısının popülasyondaki oranını göstermektedir $(\% 50)$

$$
n=\frac{388093 * 0.5 * 0.5}{388092 *(0.0255)^{2}+0.5 * 0.5}=384
$$

Araştırmada maksimum örnek hacmine ulaşmak için $p=0.50$ ve $q=0.50$ kullanılmıştır. Anket sayıs $\% 5$ artırılarak araştırma yöresinde toplam 400 tüketici ile yüz-yüze görüşülmüştür.

\section{Ödeme İstekliliği (WTP) Yöntemi}

Ödeme istekliliği, piyasada değeri bilinmeyen mal ve hizmetlerin parasal değerlerini, tüketici faydasını dikkate alarak toplumun tercihlerine göre belirlenmektedir. Ödeme istekliliğinde contingent valuation, contingent ranking, contingent choice ve conjoint analysis olmak üzere dört yöntem kullanılmaktadır (Haab ve McConnell, 2003). Koşullu Değerleme (contingent valuation) (CV) yöntemi, Willingness to pay (WTP) (ödeme istekliliğini) tahmin etmede en çok kullanılan yöntemlerden biridir. Bu yöntemde Çift-sınırl (The dichotomous choice) yani "evet-hayır" tipi soru dizisi hazırlanarak anketler yapılmaktadır (Haab ve McConnell, 2003; Del Saz-Salazar vd., 2016; Sezgin vd., 2016). The dichotomous choice model kapsamında her bir katılımcıya iki teklif sunulmaktadır. İkinci teklif miktarı, ilk teklif miktarına verilen cevaba bağlı olarak sunulmaktadır. İlk teklife verilen yanıt "evet" ise başlangıç teklifini ( $B_{I}$ ) ödemeyi istemektedir, daha sonra katılımcıya daha yüksek olan ikinci fiyat teklifi ( $B_{U}$ ) sunulmaktadır. Eğer katılımcı ilk teklif miktarına "hayır" yanıtını vermiş ise ilk teklif miktarını ödemeyi kabul etmemektedir ve bu aşamadan sonra daha düşük olan ikinci bir fiyat teklifi $\left(B_{L}\right)$ sunulmaktadır. Böylece tüketicilerin ödeme isteğinde olacağı fiyat sınırları belirlenmiş olmaktadır (Del Saz-Salazar vd., 2015; Sezgin vd., 2016). 
The dichotomous choice contingent valuation yönteminde sorulan sorular için verilen cevaplar dört kategoriye ayrılmaktadır. Bunlar; "hayır, hayır"; "hayır, evet"; "evet, hayır" ve "evet, evet" olarak kategorize edilmektedir. Bu durumu gösteren "i" katılımcısı için WTP formül aşağıdadır (Gabrielyan et al., 2016).

(3) $\operatorname{Pr}\left(Y_{i}=j\right)=\left\{\begin{array}{c}=\operatorname{Pr}\left(W T P<B_{D}\right)=G\left(\alpha-\rho \mathrm{B}_{D}+\lambda^{\prime z_{i}}\right)=\frac{e^{\alpha-\rho \mathrm{B}_{D}}+\lambda / z_{i}}{1+e^{\alpha-\rho \mathrm{B}_{D}}+\lambda / z_{i}} \\ 2 \text { if } B_{U} \leq W T P_{i}<B_{I} \\ 3 \text { if } B_{I} \leq W T P_{i}<B_{P} \\ \text { 4 if } W T P_{i} \geq B_{P}\end{array}\right.$

(1) $\left(-\infty, B_{L}\right)$ katılımcıların WTP' si her iki teklifi de reddettiği zaman (hayır, hayır) sunulan daha düşük olan fiyat teklifinin $B_{L}$ altında olduğu anlamına gelmektedir; (2) katılımcıların WTP' si [ $B_{L}, B_{I}$ ) ilk fiyat teklif ( $\left.B_{I}\right)$ miktarını reddettiği fakat daha düşük olan fiyat teklifini $\left(B_{L}\right)$ kabul ettiği (hayır, evet) zaman düşük fiyat teklifi $\left(B_{L}\right)$ ve başlangıç fiyat teklifi $\left(B_{I}\right)$ arasında olduğu ifade edilmektedir; (3) [ $B_{\mathrm{I}} B_{U}$ ) katılımcıların WTP' si ilk teklif fiyatını ( $\left.B_{I}\right)$ kabul ettiğgi fakat daha yüksek olan teklif fiyatını $\left(B_{U}\right)$ reddettiği (evet, hayır) zaman ilk fiyat teklifinden yüksek fakat daha yüksek olan fiyat teklifinden ( $B_{U}$ ) düşüktür; (4) $\left[B_{U},+\infty\right.$ ) katılımcıların WTP' si her iki fiyat teklifini kabul ettiği zaman (evet, evet), daha yüksek olan fiyat teklifinin üzerindedir sonucu çıkmaktadır.

Ödeme İstekliliğinde (WTP'de) amaç, katılımcıların ödemek isteyecekleri maksimum ve minimum değerleri tespit edip, daha sonra bu miktarı etkileyen demografik, sosyal ve ekonomik faktörleri tespit ederek ödeme istekliliğine etkisini araştırmaktır.

Çift-sınırlı model kapsamında her bir katılımcıya iki teklif önerilmektedir. İkinci teklif seviyesi başlangıç veya ilk teklif miktarına verilen cevaba bağlı olarak sunulmaktadır. İlk teklife verilen yanıt "evet" ise başlangıç teklifini $\left(B_{I}\right)$ ödemeyi istemektedir, daha sonra katılımcıya daha yüksek olan ikinci fiyat teklifi $\left(B_{U}\right)$ sunulmaktadır. Eğer katılımcı ilk teklif miktarına "hayır" yanıtını vermiş ise ilk teklif miktarını ödemeyi kabul etmemektedir ve bu aşamadan sonra daha düşük olan ikinci bir fiyat teklifi ( $B_{L}$ ) sunulmaktadır (Sezgin vd., 2016).

Çalışmada hane halkına belediyenin alt yapı hizmetlerini düzelterek tüketicilere daha güvenilir içme suları için ödeme istekliliğinde bulunup bulunmayacakları araştırılmıştır. Tüketicilere bir litre şişe su için ortalama olarak ödedikleri bir TL'lik tutar dikkate alınarak bu bedelin $\% 50$ aşağısı ve $\% 50$ fazlası dikkate alınarak maksimum ve minimum sınırlar belirlenmiş olup, bu sınırlar arasında onar kuruş artırımlar yapılarak tüketiciye rastgele on altı fiyat sunulmuştur. Daha sonra bu fiyatlarla tüketicinin demografik, sosyal ve ekonomik özelliklerine göre ödeme istekliliğinde bulunup bulunmadığ1 belirlenmiştir.

\section{ARAŞTIRMA BULGULARI VE TARTIŞMA}

\section{İçme Suyu İçin Ödeme İstekliliğinde Kullanılan Değişkenlerin Açıklaması}

İçme suyu için ödeme istekliliğinde bulunan hane halkı ile ilgili değişkenler ve açıklamaları Tablo 1 'de verilmiştir. 
Tablo 1. Ödeme istekliliği analizinde kullanılan değişkenlerin betimleyici istatistikleri

\begin{tabular}{|c|c|c|c|}
\hline Değişkenler & Açıklamaları & Ortalama & Sd hata \\
\hline SABİT & & & 0.557 \\
\hline HBIREY & Hanedeki birey sayısı (1-10) & 4.125 & 0.096 \\
\hline OYAS & Yaș kategorisi $36-55$ yıl $=1$, diğerleri $=0$ & 0.505 & 0.237 \\
\hline OGELIR & Ailenin geliri 2001-3800 TL aras1 (\%) & 42.5 & 22.8 \\
\hline ESNAF & Esnaf $=1$, diğerleri $=0$ & 0.080 & 0.428 \\
\hline PASTTUK & $\begin{array}{l}\text { Hanenin günlük pastörize süt tüketim miktarı (0- } \\
667 \mathrm{ml})\end{array}$ & 59.948 & 0.001 \\
\hline DEGITIM & Eğitim kategorik, $0-5$ y1l $=1$, diğerleri $=0$ & 0.188 & 0.287 \\
\hline MYMADN & $\begin{array}{l}\text { Hanenin günlük meyveli madensuyu tüketim } \\
\text { miktarı (0-4 şişe) }\end{array}$ & 1.656 & 0.007 \\
\hline CAYTUK & $\begin{array}{l}\text { Hanenin günlük çay tüketim miktarı } \\
\text { çay bardağ } 1)\end{array}$ & 44.000 & 0.003 \\
\hline MEYVESU & $\begin{array}{l}\text { Hanenin günlük meyve suyu tüketim miktarı }(0 \text { - } \\
1.000 \mathrm{ml})\end{array}$ & 141.252 & 0.001 \\
\hline SFATURA & Hane aylık su faturası (10-60 TL arası) & 34.525 & 0.008 \\
\hline CESMEF & $\begin{array}{l}\text { Çeşmeden bir litre su getirme maliyeti }(0-0.5 \\
\text { TL) }\end{array}$ & 0.101 & 0.732 \\
\hline SISE & $\begin{array}{l}\text { İçme suyunu, şişe sulardan karşılama }=1 \text {, } \\
\text { diğerleri }=0\end{array}$ & 0.215 & 0.273 \\
\hline SUTUK & Hane başına günlük içme suyu tüketimi (lt) & 7.21 & 3.10 \\
\hline AMNTWTP1 & $\begin{array}{l}50-150 \mathrm{krs} \text { arası rastgele belirlenen fiyat (bu fiyatı } \\
\text { tüketicinin ödemeye istekli olup, olmadığının } \\
\text { sorulması) } \mathrm{E}=1 \text { ve } \mathrm{H}=0\end{array}$ & 0.535 & 0.004 \\
\hline
\end{tabular}

Haneler ortalama 4.125 kişiden oluşmakta olup, hane halkında daha güvenli içme suyu için ödeme istekliliğinde bulunanlarının oranı \%53.5'dir. Aile reislerinin \%50.5'i orta yaș grubunda. \%42.5'i orta gelir grubunda ve \%19'u düşük eğitim grubunda olup, \%8'i esnaftır. Hanelerde günlük ortalama $60 \mathrm{ml}$ pastörize süt. 1.7 şişe meyveli maden suyu, yaklaşık 44 çay bardağ çay, $141.3 \mathrm{ml}$ meyve suyu tüketilmektedir. Hanelerde ortalama su faturası 10-60 TL arasıdır. Meşhur çeşmelerden su getirmenin birim maliyeti yaklaşık 0.50 kuruştur. Hane halkının yaklaşık \%21.5'i içme suyunu hazır sudan karşılamaktadır.

Ödeme istekliliğinde verilen fiyata göre kabul durumları Tablo 2'de verilmiştir.

Tablo 2. Ödeme istekliliğinde verilen fiyata göre kabul ve ret durumları

\begin{tabular}{cccccc}
\hline $\begin{array}{c}\text { Verilen fiyat } \\
\text { (Krş/lt) }\end{array}$ & \multicolumn{5}{c}{ Kabul durumu } \\
\cline { 2 - 6 } & Hayır-Hayır & Hayır-Evet & Evet-Hayır & Evet-Evet & Toplam \\
\hline 50 & 5 & 5 & 19 & 7 & 36 \\
60 & 5 & 4 & 18 & 4 & 31 \\
70 & 8 & 9 & 16 & 5 & 38 \\
80 & 15 & 4 & 13 & 10 & 42 \\
90 & 20 & 6 & 5 & 5 & 36 \\
100 & 12 & 3 & 5 & 7 & 27 \\
110 & 14 & 9 & 16 & 1 & 40 \\
120 & 18 & 1 & 7 & 7 & 33 \\
130 & 23 & 4 & 8 & 14 & 49 \\
140 & 4 & 0 & 14 & 10 & 28 \\
150 & 17 & 1 & 15 & 7 & 40 \\
\hline Toplam & 141 & 46 & 136 & 77 & 400 \\
\hline
\end{tabular}




\section{Ödeme İstekliliğinde Kullanılan Logit Model}

Ödeme istekliliği analizlerinde probit, logit veya tobit model kullanılabilmektedir. Bilindiği üzere probit ile logit analiz sonuçları birbirine yakındır. Aradaki fark probitte elde edilen sonucu bir katsayı ile çarpınca logiti vermektedir. Logitte elde edilen sonucu probitte elde etmek için de sonucu bir katsayı ile çarpmak yeterli olmaktadır (Uzundumlu 2011).

Tablo 3'te yalnızca istatistiki açıdan önemli olan değişkenler açıklanmıştır.

Tablo 3. Ödeme istekliliğinde kullanılan logit modelin tahmini parametre değerleri

\begin{tabular}{|c|c|c|}
\hline Değişkenler & Katsayılar & Standart hata \\
\hline SABİT & 1.973 & 0.557 \\
\hline HBIREY & $-0.188 * *$ & 0.096 \\
\hline ESNAF & $-1.064 * *$ & 0.428 \\
\hline OGELIR & -0.006 & 0.228 \\
\hline OYAS & 0.245 & 0.237 \\
\hline DEGITIM & $-0.529^{*}$ & 0.287 \\
\hline PASTTUK & 0.000 & 0.001 \\
\hline MYMADN & 0.006 & 0.007 \\
\hline CAYTUK & -0.003 & 0.003 \\
\hline MEYVESU & $0.002 * * *$ & 0.001 \\
\hline SFATURA & 0.007 & 0.008 \\
\hline CESMEF & $1.264^{*}$ & 0.732 \\
\hline SISE & -0.282 & 0.273 \\
\hline AMNTWTP1 & $-0.015 * * *$ & 0.004 \\
\hline $\begin{array}{l}\text { Log likelihood } \\
\text { Chi squared }\left(x^{2}\right)\end{array}$ & & \\
\hline
\end{tabular}

Ailede birey sayısı arttıkça hanelerin daha temiz, hijyenik ve kaliteli su tercihi azalmaktadır. İstatistiksel açıdan bu durum $\mathrm{p} \leq 0.05$ 'de önemlidir. Bunun nedeni ödeme istekliliği birim başına olduğu için tüketim arttıkça ödenecek meblağın yüksekliğini düşünen bireyler suda ilave bir ödeme isteğine gerek olmadığını düşünmektedirler. Bilgic vd. (2008), Bilgic (2010) ve Rananga ve Gumbo (2015)'de bu çalışmada olduğu gibi hanede birey sayısı arttıkça içme suyu için tüketicilerin ödeme istekliliğinin azaldığını tespit etmişlerdir.

Aile reisinin mesleği içme suyunda ödeme isteğinde önemli bir etkendir. Aile reisinin esnaf olması ödeme istekliliğinde negatif etkiye sahip olup, istatistiksel açıdan bu durum $p \leq 0.05$ 'de önemlidir. Aile reisi esnaf olan ailelerin bir kısmı şişe su pazarlamakta veya daha düşük fiyattan alabilmektedir. İlave suya para ödemesi yapmak istemeyen bu aileler suda ödeme istekliliğini düşünmemektedirler. Rananga ve Gumbo (2015)'de gelir seviyesi düşük olan mesleklerde çalışan bireylerin, özellikle de ev hanımlarının ödeme istekliliğinde olmadıklarını tespit etmişlerdir.

Düşük eğitim grubunda yer alan hane reislerinin eğitimleri 0-6 yıldır. Bu hanelerde eğitim yılı azaldıkça hanelerin ödeme istekliliği azalmaktadır. Bu durum $\mathrm{p} \leq 0.10$ 'da önemlidir. Bilgic vd. (2008), Yacob vd. (2013), Mezgebo ve Ewnetu (2015) ve Twerefou vd. (2015)'in belirttikleri gibi eğitim çalışmalarında, hijyenik sulara tüketicilerin ulaşmasının çok önemli olduğunu bu nedenle tüketicilerin eğitim seviyeleri yükseldikçe güvenilir sular için ödeme isteği artmaktadır.

Ailelerde ödeme istekliliği ile meyve suyu tüketimi arasında pozitif bir ilişki vardır. Bu durum $\mathrm{p} \leq 0.01$ 'de önemlidir. Yani hanelerde meyve suyu tüketimi arttıç̧a içme suyu için ödeme istekliliği artmaktadır. Bunun nedeni Erzurum ilinde hanelerin önemli bir kısmı içme sularının besin içeriğine güvenmediği için meyve suyu tüketmektedir. Meyve suyu ile insanların daha sağlıklı olacağ düşüncesine sahip olan bu haneler suyun güvenilir ve kaliteli bir şekilde kendilerine ulaştırılmasında ek ödemede bulunabileceklerini belirtmişlerdir. Lee (2015)'inde belirtiği gibi meyve suyunda doğal hammadde kullanım oranı arttıkça, tüketicilerin bu gıdalara daha fazla ödemede bulunma isteği artmaktadır. 
Hanelerde çeşme suyunun maliyeti arttığında su için ödeme istekliliğgi artmaktadır. Bu durum $\mathrm{p} \leq 0.10$ 'da önemlidir. Çeşme suyu, genelde maliyeti olmadan mahalle çeşmesinden karşılanmaktadır. Ancak bazı tüketiciler mahalle çeşmelerinin yerine meşhur çeşmelerden su getirmekte bu nedenle araçların yakıt masrafı, su masrafını oluşturmaktadır. Bu nedenle meşhur çeşmeler için benzin masrafı arttıkça tüketiciler evlere kadar gelebilen kaliteli şebeke suyuna fazladan ödemede bulunmak istemektedirler. Rauf vd. (2015) ve Twerefou vd. (2015)'in belirttiği gibi ikame ürünlerin ulaşımı zorlaştıkça ve fiyatları artıkça güvenilir şebeke suyu için tüketicilerin ödeme istekliliği artmaktadır.

Ödeme isteğinde tüketiciye sunulan fiyat arttıkça tüketicilerin su için ödeme isteği azalmaktadır. Bu durum $\mathrm{p} \leq 0.01$ 'de önemlidir. Tüketicilerden 50-80 TL için ödeme istekliliğinde bulunanların oranı \%65.7, 90-120 TL için bu oran \%53.9 ve 130-150 TL için \%41.9'dur. Tüketicilere bir litre suyun fiyatı 50-150 kuruş arasında rastgele fiyatlar sunulmuş fiyatlar 150 kuruşa yaklaşınca tüketiciler ödenecek meblağın yüksekliği nedeniyle genelde kabul etmezken şişe suyun fiyatı ile neredeyse aynı olan 50 kuruşu kabul etmektedirler. Eren vd. (2008), Bilgic (2010) ve Del Saz-Salazar vd. (2016) de bu çalışmada olduğu gibi tüketiciye sundukları ödeme istekliliği bedeli arttıkça tüketicilerin içme suyu için ödeme istekliliğinin azaldığını belirtmişlerdir.

\section{SONUÇ VE ÖNERILER}

Nüfus artışı ve teknolojik ilerlemeler nedeniyle insanların daha sağlıklı yiyecek ve içeceklere ulaşma maliyetleri artmaktadır. Erzurum ilinde de nüfusun artı̧̧ nedeniyle halkın alışmış olduğu kaynak suyu yerine alışı olmadıkları ve hijyen ve kalite durumunu beğenmedikleri baraj suyuna olan şikayetleri giderek artmıştır. $\mathrm{Bu}$ nedenle bu çalışmada belediye hizmetlerinin artırılmasıyla sunun hijyen ve kalitesindeki iyileştirmeler için halkın ödeme isteğinde olup olmayacağı araştırılmıştır. Çalışmada suyun litresi için tüketicilerin 50 ile 150 kuruş arasında fazladan ödeme yapıp yapmayacakları belirlenmeye çalışılmıştır. Çalışmada hanehalkının içme suyu için 50-80 krş/lt ödeme istekliliğinde bulunanların oranı yaklaşık \%66 olduğu ve tüketiciye sunulan teklif fiyatı arttıkça tüketicilerin içme suyu için ödeme istekliliği azalmaktadır. Hanelerin 4.125 bireyden oluştuğu ve bireylerin kişi başına 1.75 litre su içtiği tespit edilmiştir. Ayrıca hane halkının ortalama olarak 0.50 kuruş ödeme istekliliğinin bulunduğu tespit edilmiştir. Basit bir hesap yapıldığında $(4.125 * 1.75 * 0.5 * 30)$ aylık harcanılan içme suyu bedeli yaklaşı 110 TL olmaktadır. Çalışmada hanelerin ortalama belediyeye ödemiş oldukları su faturası 34.5 TL dikkate alınınca, tüketiciler yaklaşık olarak 3.2 kat daha fazla güvendikleri su için ödeme istekliliğinde bulunabilecekleri tespit edilmiştir. Ayrıca hane halkının içme suyu için ödeme istekliliğinde bulunmasını etkileyen 13 değişkenden 5'i anlamlı olarak tespit edilmiştir. $\mathrm{Bu}$ anlamlı değişkenlerden meyve suyu tüketimi arttıkça bireylerin içme suyu için ödeme istekliliğinde bulunması ihtimali artmaktadır. Diğer 4 faktör (hane birey sayısı, hane reisinin düşük eğitim seviyesi, hane reisinin esnaf olması ve ödeme isteğindeki fiyatın artması) içme suyu için ödeme istekliliğini azaltmaktadır. Ĕger Belediyeler tüketicilerin istediği hijyen ve kalite düzeyini sağlayacak tesisin masrafının karşılanmasında tüketicilerin desteklerini alacaklardır. Bu nedenle belediyenin su kalitesini iyileştirmeye yönelik yapacağı yatırımları tüketiciler destekleyeceklerdir. Sonuçta belediyeler içme suyunu iyileştirmeye yönelik yatırım yaptı̆̆ında, tüketiciler talep ettikleri içme suyu kalitesine evlerinde erişme imkânı bulacaklardır.

\section{KAYNAKÇA}

Alaş, A, Tunç, T, Kışoğlu, M. and Gürbüz, H. (2009). An investigation on prospective teachers' conscious water consumption: Atatürk university sample. Journal of Education Faculty, 11(2), 37-49.

Bilgic, A. (2010). Measuring willingness to pay to improve municipal water in southeast Anatolia, Turkey. Water Resources Research, 46(12), DOI: 10.1029/2009WR009010.

Bilgic, A., Eren, G. and Florkowski, W. J. (2008). Willingness to pay for potable water in the southeastern Turkey: an application of both stated and revealed preferences valuation method. The Southern Agricultural Economics Association Annual Meeting February 2-6, Teksas, USA. 
Brouwer, R., Job, F. C., van der Kroon, B. and Johnston, R. (2015). Comparing willingness to pay for improved drinking-water quality using stated preference methods in rural and urban Kenya. Applied Health Economics and Health Policy, 13(1), 81-94.

Del Saz-Salazar, S., García-Rubio, M. A., González-Gómez, F. and Picazo-Tadeo, A. J. (2016). Managing water resources under conditions of scarcity: on consumers' willingness to pay for improving water supply infrastructure. Water Resources Management, 30(5), 1723-1738.

Del Saz-Salazar, S., González-Gómez, F. and Guardiola, J. (2015). Willingness to pay to improve urban water supply: the case of Sucre, Bolivia. Water Policy, 17 (1), 112-125.

Eren, G., Bilgiç, A., Karli, B. and Miran, B. (2008). GAP bölgesi'nde kaliteli içme suyunun fiyatlandırılmasına etki eden faktörler. Turkish Journal of Agricultural Economics, 14(2), 67-74.

Gschwandtner, A., Jang, C. and McManus, R. (2018). Improving drinking water quality in South Korea: a choice experiment. Conference of International Association of Agricultural Economists. July 28-August 2 Vancouver, Canada.

Guilfoos, T., Hayden, S., Uchida, E., Oyanedel-Craver, V. (2019). WTP for water filters and water quality testing services in Guatemala. Water Resources and Economics (In Press, 100139).

Haab, T. C., and McConnell, K. E. (2003). Valuing environmental and natural resources: the econometrics of non-market valuation. Northampton, MA: Edward Elgar.

Karahan, F. and Angın, İ. (2008). Yeşil alan uygulamalarında su tüketiminin asgariye indirilmesi için Sukkulent bitki türlerinden yararlanma. TMMOB 2. Su Politikalarl Kongresi 20-22 Mart, Ankara, Türkiye.

Lee, P. Y., Lusk, K., Mirosa, M. and Oey, I. (2015). An attribute prioritization-based segmentation of the Chinese consumer market for fruit juice. Food Quality and Preference, 46, 1-8.

Lyytimäki, J., and Assmuth, T., 2015. Down with the flow: public debates shaping the risk framing of artificial groundwater recharge. GeoJournal, 80(1), 113-127.

Manju, S. and Sagar, N. (2017). Yenilenebilir enerji entegre tuzdan arındırma: Hindistan'da gelecekteki tatlı su kıtlığının üstesinden gelmek için sürdürülebilir bir çözüm. Yenilenebilir ve Sürdürülebilir Enerji İncelemeleri, 73, 594-609.

Mezgebo, G. K. and Ewnetu, Z. (2015). Households willingness to pay for improved water services in urban areas: A case study from Nebelet town, Ethiopia. Journal of Development and Agricultural Economics, 7(1), 12-19.

Newbold, P., (1995). Statistics for business and economics. New Jersey, USA: Prentice- Hall International,

Rananga, H. T. and Gumbo, J. R. (2015). Willingness to pay for water services in two communities of Mutale local municipality, South Africa: a case study. Journal of Human Ecology, 49(3), 231243.

Rauf, S., Bakhsh, K., Hassan, S., Nadeem, A. M. and Kamran, M. A. (2015). Determinants of a household's choice of drinking water source in Punjab, Pakistan. Polish Journal of Environmental Studies, 24(6), 2751-2754.

Rodríguez-Tapia, L., Revollo-Fernández, D. and Morales-Novelo, J. (2017). Household's perception of water quality and willingness to pay for clean water in Mexico City. Economies, 5(12), 1-14.

Sezgin, A. ve Uzundumlu, A. S. (2019). Organik ürün tüketimi üzerine etkili olan faktörlerin analizi; Erzurum ili örneği. IBAD Sosyal Bilimler Dergisi, Özel Sayl, 441-451.

Sezgin, A., Bilgic, A., Demir, O., (2016). Analysis of factors affecting willingness to pay for agricultural advisory service: the case of Erzurum province. The $12^{\text {th }}$ Agricultural Economics Congress, 25-27 May, Isparta, Turkey. 
Tanellari E, Bosch D, Boyle K, Mykerezi E. (2015). On consumers' attitudes and willingness to pay for improved drinking water quality and infrastructure. Water Resources Research, 51(1), 4757.

Twerefou, D. K., Tutu, K. A., Botchway, E. and Darkwah, S. (2015). Willingness-to-pay for potable water in the Accra-Tema metropolitan area of Ghana. Modern Economy, 6(12), 1285-1296.

Van Houtven, G. L., Pattanayak, S. K., Usmani, F. and Yang, J. C. (2017). What are households willing to pay for improved water access? Results from a meta-analysis. Ecological Economics, $136,126-135$.

Yacob, M. R., Dauda, S. A., Radam, A. and Samdin, Z. (2013). Household's willingness to pay for drinking water quality service improvement in Damaturu, Nigeria. Current World Environment, 8(3), 381-389. 